Nuansa Journal of Arts and Design

Volume 4 Nomor 2 September 2020

e-ISSN: 2597-405X dan p-ISSN: 2597-4041

(c) (1) This work is licensed under a Creative Commons Attribution

4.0 International License

\title{
Dramaturgi dan Transformasi Realita dalam Naskah Drama "Jalan Menyempit” Karya Joni Faisal : Analisis Unsur Dramatik Perspekstif Sosiologi dan Psikologi
}

\section{Akhyar Makaf \\ Penulis}

\section{Keywords :}

Drama Script;

Dramaturgy;

Social phenomena:

Psychological phenomena;

Transformation.

\section{Corespondensi Author}

Teater, Fakultas Seni Pertunjukan, Institut Seni Indonesia Surakarta,

Jl. Ki Hajar Dewantara No.19

Surakarta, Jawa Tengah - 57126.

Email: aku.makaf@gmail.com

\begin{abstract}
ABSTRAK
Naskah drama yang berkualitas baik adalah bahan untuk menyajikan pertunjukan teater yang baik pula. Naskah tersebut adalah karya sastra yang menjadi media bagi dramawan untuk menyampaikan pesan, gagasan, komentar, dan solusi dari permasalahan keseharian di lingkungannya, melalui unsur dramatik seperti tema, alur, penokohan, dan latar. Penelitian ini dilakukan untuk menelaah unsur-unsur dramatik, fenomena sosial, dan fenomena psikologi yang terdapat dalam naskah drama "Jalan Menyempit" karya Joni Faisal, sebagai naskah pemenang pertama lomba Penulisan Naskah Teater Nasional tahun 2017 yang diselenggarakan oleh Kementerian Pendidikan dan Kebudayaan. Naskah ini kurang dikenal karena terbatasnya publikasi. Oleh sebab itu, penelitian ini dilakukan untuk membantu masyarakat, khususnya seniman, akademisi seni teater dan seni sastra, agar bisa memperoleh informasi tentang unsur-unsur dramaturgi, keterkaitan dengan realita sosial dan realita psikologi masyarakat di Indonesia, serta proses transformasi realita menjadi peristiwa dramatik. Metode penelitian kualitatif dengan pendekatan deskriptif analitik digunakan untuk menganalisis unsur dramatik (intrinsik), lalu menghubungkannya dengan fenomena sosial-psikologi (ekstrinsik) pada naskah, menggunakan teori dramaturgi, sosiologi sastra, dan psikologi sastra. Dapat ditarik kesimpulan bahwa drama ini adalah penggambaran dari realita sosial dan realita psikologis pada saat naskah ini ditulis. Penulisnya berusaha merespon realita yang terjadi dengan menuangkan pikirannya dalam drama untuk memberikan pernyataan dan menawarkan solusi bagi berbagai permasalahan yang terjadi di masyarakat.
\end{abstract}

\footnotetext{
ABSTRACT

A good quality drama script is the material for presenting a good theater performance as well. The manuscript is a literary work that becomes a medium for playwrights to convey messages, ideas, comments, and solutions to daily problems in their environment, through dramatic elements such as themes,
} 
Akhyar Makaf

Dramaturgi dan Transformasi Realita dalam Naskah Drama "Jalan Menyempit” Karya Joni Faisal : Analisis Unsur Dramatik Perspekstif Sosiologi dan Psikologi

plot, characterizations, and settings. This research was conducted to examine the dramatic elements, social phenomena, and psychological phenomena contained in Joni Faisal's drama script "Jalan Menyempit", as the first winning script for the 2017 National Theater Script Writing competition organized by the Ministry of Education and Culture. This manuscript is less well known because of limited publication. Therefore, this research was conducted to help the community, especially artists, academics in theater and literary arts, in order to obtain information about the elements of dramaturgy, their relationship with social realities and psychological realities in Indonesia, as well as the process of transforming reality into dramatic events. Qualitative research methods with a descriptive analytic approach are used to analyze dramatic (intrinsic) elements, then relate them to socio-psychological (extrinsic) phenomena in the text, using dramaturgy theory, sociology of literature, and literary psychology. It can be concluded that this drama is a depiction of social realities and psychological realities at the time this script was written. The author tries to respond to the reality that occurs by pouring his thoughts into drama to provide statements and offer solutions to various problems that occur in society.

\section{PENDAHULUAN}

Naskah drama adalah ide yang menjadi rancangan awal dan dasar dari sebuah pertunjukan teater, yang juga lazim disebut dengan istilah drama, lakon, naskah lakon, naskah pertunjukan, dan bermacam sebutan lainnya. Naskah drama sebagai karya seni berisi pernyataan, ide, gagasan, dan pesan dari penulisnya. Di dalamnya juga berisi gambaran realita kebudayaan, fenomena yang terjadi di masyarakat, sejarah, dan semangat zaman (zeitgeist) di suatu periode tertentu. Naskah drama sebagai sebuah karya sastra, dapat dikaji secara komprehensif guna mengupas kedalaman tematik, ide/gagasan yang ditawarkan penulis, teknik penyusunan alur, proyeksi dan kompleksitas penokohan, serta kontekstualitas latar cerita terhadap realita dari permasalahan yang ada di suatu periode tertentu. Hal inilah yang menyebabkan suatu karya drama menarik untuk diteliti unsur intrinsik dan unsur ekstrinsiknya ${ }^{1}$.

Penulis naskah drama biasa disebut dengan istilah dramawan (playwright). Pada peradaban Yunani abad 5 SM, penulis drama disebut didaskalas (guru; didactic-pendidik). Dramawan berkarya dengan menyeleksi permasalahan manusia sehari-hari, lalu fokus pada masalah yang diseleksi dengan sudut pandang yang dipilihnya. Ia kemudian mengembangkan karakter-karakter yang dilengkapi dengan struktur dramatis. Proses ini dilanjutkan menjadi proses penulisan naskah drama (Riantiarno, 2011: 47). Penjelasan ini mengungkapkan bahwa penulis drama memiliki peran penting tidak hanya sebagai kreator, tetapi juga sebagai seniman yang terlibat untuk

\footnotetext{
1 Nurgiyantoro (2005:32) mengatakan, unsur intrinsik adalah unsur yang secara langsung membangun karya sastra. Unsur ini meliputi peristiwa, cerita, plot, penokohan, tema, latar, sudut pandang penceritaan dan gaya bahasa. Sedangkan unsur ekstrinsik yaitu unsur-unsur yang berada di luar karya sastra, tetapi secara tidak langsung mempengaruhi karya sastra tersebut.
} 
mendidik dan mencerdaskan masyarakat secara luas melalui media seni.

Secara teknis penciptaan karya seni, penulis naskah adalah kreator pertama dalam bentuk teks yang berisi visi, pesan, dan situasisituasi yang ingin disampaikan. Seperti yang dijelaskan Sitorus (2003: 9-10) bahwa pada proses selanjutnya sutradara akan menganalisis teks serta menyesuaikannya dengan lingkungan dan tradisi-tradisi teater yang sudah ada pada saat naskah tersebut ditulis. Ia membentuknya menjadi sebuah konsep produksi dan dibagikan kepada setiap seniman yang terlibat sehingga mereka dapat memakai konsep tersebut untuk melakukan penafsiran sendiri terhadap naskah. Penafsiran ini digunakan untuk mendukung konsep sutradara untuk bersama-sama diaplikasikan dalam sebuah produksi.

\section{METODE}

Direktorat Kesenian, Direktorat Jenderal Kebudayaan, Kementerian Pendidikan dan Kebudayaan Indonesia, pada tahun 2017 mengadakan lomba penulisan naskah lakon teater tingkat nasional. Sampai akhir batas pengumpulan naskah bagi peserta lomba, tercatat 343 judul naskah yang masuk ke meja panitia. Dari keseluruhan naskah yang masuk, kemudian dipilih tiga naskah yang akan menempati posisi juara terbaik satu, dua, tiga. Peringkat selanjutnya adalah juara Harapan 1, dan seterusnya sampai Harapan VI. Dapat disimpulkan bahwa kesepuluh naskah pemenang lomba ini adalah naskah-naskah terbaik yang dipilih dewan juri yang diketuai Noorca M. Massardi, dengan anggota yang terdiri dari ; Agus Noor, Arthur S. Nalan, Nur Sahid, dan Warih Wisatsana. Kemudian, kesepuluh naskah pemenang lomba diterbitkan dalam sebuah buku kumpulan naskah pemenang lomba yang dicetak secara terbatas.

Naskah-naskah baru hasil pergulatan pemikiran penulis-penulis muda Indonesia ini menjadi penting bagi tonggak perkembangan naskah teater Indonesia di masa depan. Sebab, pertumbuhan jumlah naskah drama sebagai sebuah karya sastra di Indonesia belum sebanding dengan karya-karya sastra populer lain seperti novel, cerpen, puisi, dan lain sebagainya. Untuk itu, usaha yang dilakukan Direktorat Kesenian ini layak diapresiasi karena berhasil memacu semangat penulis muda untuk menulis naskah drama. Hal ini tampak dari cukup banyaknya jumlah naskah yang masuk. Jumlah ini sekaligus memperlihatkan bahwa saat ini minat generasi muda di Indonesia untuk menulis naskah drama masih cukup tinggi. Perihal menggembirakan berikutnya adalah kualitas kesepuluh naskah pemenang lomba ini yang dapat dikatakan layak untuk dipentaskan dan dikaji sebagai wacana mutakhir tentang perkembangan naskah drama di Indonesia.

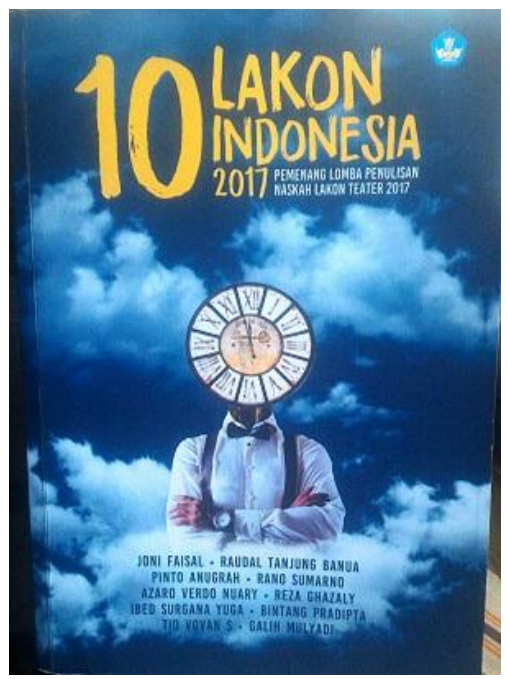

Gambar 1. Sampul depan dari buku Kumpulan 10 Naskah Pemenang Lomba Penulisan Naskah Lakon Teater 2017 yang dilaksanakan oleh Kementerian Pendidikan dan Kebudayaan. Sumber foto : penulis.

Teknik analisis data yang digunakan adalah metode deskriptif analitik, yaitu metode memahami objek dengan menguraikan, mengklasifikasikan, memisah-misahkan, lalu dianalisis sesuai dengan tujuan penelitian untuk menghasilkan simpulan. Hasil analisis kemudian disajikan secara naratif. Data primer berupa karya dan dokumen dideskripsikan ke dalam kata-kata dan kalimat (Ratna, 2010:336-337).

Objek dari penelitian ini adalah naskah pemenang Juara 1 pada lomba Penulisan Naskah Lakon Teater tahun 2017 yang diadakan oleh Kebudayaan Direktur Jenderal Kebudayaan, Kementrian Pendidikan dan Kebudayaan dengan berjudul "Jalan Menyempit" yang ditulis oleh Joni Faisal ini berkisah tentang perjuangan masyarakat kecil dalam menghadapi kerumitan permasalahan sosial sehari-hari di sebuah kota besar.

Drama surrealis ini secara unik memperlihatkan absurditas masyarakat perkotaan di masa sekarang. Awal permulaan dari permasalahan cukup sepele, yaitu rombongan 
Dramaturgi dan Transformasi Realita dalam Naskah Drama "Jalan Menyempit" Karya Joni Faisal : Analisis Unsur Dramatik Perspekstif Sosiologi dan Psikologi

pengantar jenazah yang terkendala membawa keranda akibat jalan menuju pemakaman yang sudah sangat sempit akibat pembangunan, sehingga sudah tidak bisa dilewati. Kemudian masalah ini terus bergulir dan mengungkap permasalahan-permasalahan pelik yang terjadi di keseharian masyarakat kecil yang sering dieksploitasi oleh pihak yang lebih berkuasa.

Permasalahan-permasalahan dalam naskah ini lebih banyak dihadirkan dalam simbol-simbol yang mengungkap realitas di masyarakat yang ironis. Akan tetapi, penulis naskah ini berhasil menghadirkannya dengan satir yang efektif. Pembaca bisa dibuat tertawa sekaligus merasakan kemirisan dari apa yang sedang diungkap.

Data diperoleh dengan melakukan telaah terhadap naskah drama yang sudah tersedia dalam bentuk dokumen tertulis. Hal ini dilakukan untuk mengkaji elemen dramaturginya, guna menjelaskan unsur tematik, jalinan plot, kompleksitas penokohan, dan kontekstual setting cerita terhadap fenomena sosial dan psikologis masyarakat di Indonesia yang dihadirkan dalam naskah. Teknik analisis data yang akan digunakan dalam penelitian ini adalah metode deskriptif analitik, yaitu metode memahami objek dengan menguraikan, mengklasifikasikan, memisah-misahkan, lalu menganalisis data sesuai dengan tujuan penelitian untuk menghasilkan simpulan (Ratna, 2010: 336).

Data awal diperoleh dengan melakukan analisis unsur-unsur dramaturgi yang ada di dalam masing-masing naskah. Unsur-unsur yang akan dianalisis adalah unsur alur, penokohan, latar cerita, dan tematik. Berikutnya, data yang diperoleh dari hasil telaah unsur-unsur struktur naskah akan dikaitkan dengan fenomena sosial dan psikologis di masyarakat Indonesia yang dihadirkan lewat jalinan kisah dari peristiwa, konflik tokoh-tokoh, latar tempat, waktu, dan suasana yang dihadirkan dalam naskah.

Penulis mengurai unsur-unsur dramatik dari naskah, dan menjelaskannya secara detail, lalu menganalisis fenomena-fenomena sosialnya dengan pendekatan sosiologis, menggunakan teori sosiologi sastra. Selain itu, peneliti juga akan menguraikan deskripsi penokohan menggunakan pendekatan psikologi sastra. Hal ini dilakukan untuk melihat bagaimana proses transformasi realita sosial dan psikologis di keseharian menjadi realita dramatik yang merupakan hasil rekayasa kreatif penulis naskah.

\section{HASIL DAN PEMBAHASAN}

Hasil

Tabel 1. Fenomena Sosial Antara Tahun 2000-2017 Di Indonesia (Pasca Reformasi Politik)

\begin{tabular}{|l|l|}
\hline \multicolumn{1}{|c|}{ FENOMENA SOSIAL } & \multicolumn{1}{c|}{ FENOMENA PSIKOLOGIS } \\
\hline PERUBAHAN SOSIAL & $\begin{array}{l}\text { EUFORIA KEBEBESAN PASCA KONTROL } \\
\text { KETAT. }\end{array}$ \\
$\begin{array}{l}\text { Kebebasan. Kesempatan mulai merata. Persaingan } \\
\text { sosial semakin ketat. }\end{array}$ & $\begin{array}{l}\text { Kebebasan yang ber-dampak positif dan negatif. } \\
\text { Positif: meningkatnya kreativitas, tingkat } \\
\text { kenyamanan. Berdampak negatif karena } \\
\text { Retidaksiapan individu menyikapi perubahan yang } \\
\text { cepat. }\end{array}$ \\
\hline
\end{tabular}




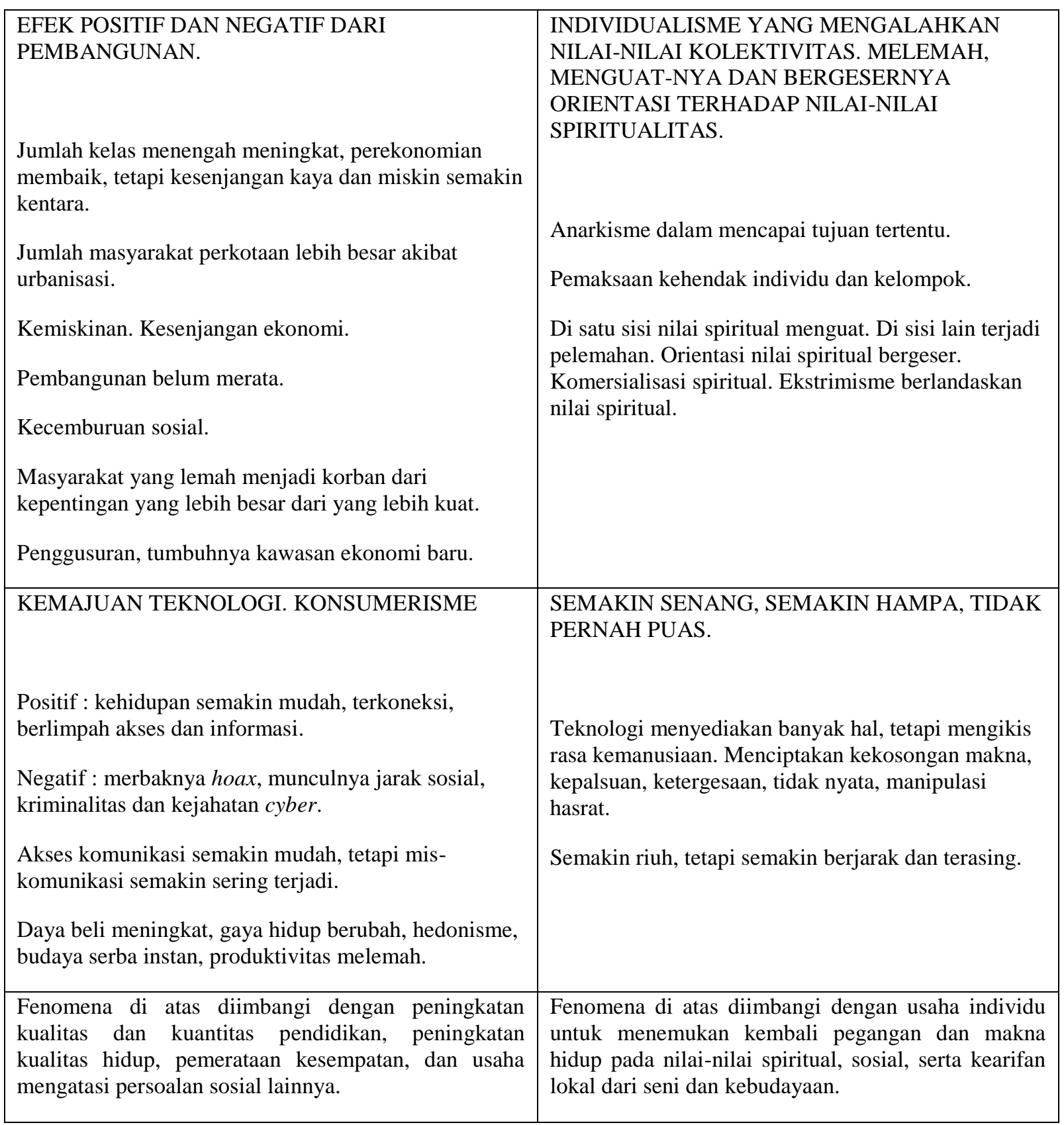

Tabel 2. Deskripsi Peristiwa Dramatik \& Realita Sosial Naskah “Jalan Menyempit"

\begin{tabular}{|c|l|l|l|}
\hline NO & PERISTIWA DRAMATIK & \multicolumn{1}{|c|}{ REALITA SOSIAL } & \multicolumn{1}{c|}{ MAKNA } \\
\hline 1 & $\begin{array}{l}\text { Pemakaman umum yang } \\
\text { susah diakses masyarakat }\end{array}$ & $\begin{array}{l}\text { Masyarakat miskin yang } \\
\text { memiliki akses terbatas untuk } \\
\text { mendapatkan fasilitas dan } \\
\text { pelayanan publik yang layak. } \\
\text { layak bagi masyarakat kecil yang semakin } \\
\text { sulit, dan cenderung diabaikan, karena } \\
\text { kalah oleh kepentingan orang yang lebih } \\
\text { kuat dan berkuasa. }\end{array}$ \\
\hline 2 & $\begin{array}{l}\text { Masyarakat kecil yang } \\
\text { dipersulit birokrasi }\end{array}$ & $\begin{array}{l}\text { Birokrasi yang rumit dan dan } \\
\text { seringkali tidak efektif bagi } \\
\text { masyarakat kecil. }\end{array}$ & $\begin{array}{l}\text { Tebang pilih penegakan hukum dan } \\
\text { pelayanan publik, sehingga masih terjadi } \\
\text { diskriminasi dan praktek pemerasan legal } \\
\text { dan ilegal. }\end{array}$ \\
\hline 3 & Penguasa yang manipulatif & Suara rakyat yang digunakan \\
\hline
\end{tabular}


Dramaturgi dan Transformasi Realita dalam Naskah Drama "Jalan Menyempit” Karya Joni Faisal : Analisis Unsur Dramatik Perspekstif Sosiologi dan Psikologi

\begin{tabular}{|c|c|c|c|}
\hline & & $\begin{array}{l}\text { hanya untuk } r \text { kepentingan } \\
\text { elektoral dan mengabaikan } \\
\text { kebutuhan bagi mereka } \\
\text { membutuhkan pelayanan } \\
\text { setelah seorang pejabat publik } \\
\text { mendapatkan amanah dan } \\
\text { kekuasaan. }\end{array}$ & $\begin{array}{l}\text { jabatannya, sehingga melupakan janji } \\
\text { politik dan keberpihakannya pada } \\
\text { masyarakat banyak yang lebih lemah, } \\
\text { adalah fenomena yang masih sering } \\
\text { terjadi. }\end{array}$ \\
\hline 4 & Penguasa yang feodalistik & $\begin{array}{l}\text { Pejabat yang seharusnya } \\
\text { melayani, malah mempersulit } \\
\text { dan selalu minta dilayani. }\end{array}$ & $\begin{array}{l}\text { Pola pikir mencari keuntungan, bukan } \\
\text { menjadi pelayan publik yang amanah. }\end{array}$ \\
\hline 5 & $\begin{array}{l}\text { Bawahan yang patuh dan } \\
\text { menutup mata } \\
\text { ketidakamanahan } \\
\text { atasannya. }\end{array}$ & $\begin{array}{l}\text { Banyaknya masyarakat kecil } \\
\text { yang memanfaatkan sesama } \\
\text { masyarakat kecil r demi } \\
\text { kepentingan pribadi dan } \\
\text { kepentingan orang yang lebih } \\
\text { berkuasa. }\end{array}$ & $\begin{array}{l}\text { Masih adanya masyarakat kecil yang } \\
\text { pragmatis dan tidak berempati dengan } \\
\text { kesulitan masyarakat kecil lainnya, } \\
\text { sehingga ia tega ikut serta } \\
\text { menyengsarakan masyarakat yang } \\
\text { seharusnya ia bantu. }\end{array}$ \\
\hline & $\begin{array}{l}\text { Solusi yang ditawarkan } \\
\text { penulis dan pernyataannya di } \\
\text { dalam naskah: }\end{array}$ & \multicolumn{2}{|c|}{$\begin{array}{l}\text { Dialog tokoh anak-anak: } \\
\text { (KOOR) Saya orang miskin.. Saya orang miskin.. Saya orang kaya.. Saya } \\
\text { orang kaya.. Saya minta anak.. Saya minta anak.. Siapa namanya.. Siapa } \\
\text { namanya.. Namanya Cinta.. Namanya Cinta.. Cinta harus pergi ke rumah } \\
\text { orang miskin.. }\end{array}$} \\
\hline
\end{tabular}

Tabel 3. Deskripsi Peristiwa Dramatik \& Realita Psikologis

\begin{tabular}{|c|c|c|c|}
\hline NO & PERISTIWA DRAMATIK & REALITA PSIKOLOGIS & MAKNA \\
\hline 1 & $\begin{array}{l}\text { Konflik dan kemarahan } \\
\text { keluarga pengantar jenazah } \\
\text { kepada Pak Lurah. }\end{array}$ & $\begin{array}{l}\text { Kejengkelan masyarakat kelas } \\
\text { bawah atas ketidakadilan dan } \\
\text { kesulitan akibat kerumitan } \\
\text { birokrasi dari pejabat yang } \\
\text { seharusnya melayani } \\
\text { masyarakat. }\end{array}$ & $\begin{array}{l}\text { Masyarakat kecil belum menjadi prioritas } \\
\text { dalam pelayanan publik dan mengalami } \\
\text { diskriminasi dalam struktur sosial, sehingga } \\
\text { mereka seringkali mudah terpancing emosi } \\
\text { dan kemudian justru dimanfaatkan oleh } \\
\text { orang tidak bertanggung jawab. }\end{array}$ \\
\hline 2 & $\begin{array}{l}\text { Kesedihan jenazah atas } \\
\text { kerumitan yang dialaminya } \\
\text { ketika akan dimakamkan. }\end{array}$ & $\begin{array}{l}\text { Kesedihan masyarakat kecil, } \\
\text { dalam menghadapi } \\
\text { permasalahan darurat dan } \\
\text { penting yang seringkali } \\
\text { menjadi objek komersialisasi } \\
\text { dan eksploitasi akibat } \\
\text { kerumitan birokrasi. }\end{array}$ & $\begin{array}{l}\text { Masyarakat lemah seringkali mengalami } \\
\text { eksploitasi dan menjadi objek kerumitan } \\
\text { birokrasi, sehingga seringkali menimbulkan } \\
\text { permasalahan emosi yang sering berdampak } \\
\text { negatif. }\end{array}$ \\
\hline 3 & Penguasa yang manipulatif & $\begin{array}{l}\text { Suara rakyat yang digunakan } \\
\text { hanya untuk kepentingan } \\
\text { elektoral, tetapi setelah } \\
\text { terpilih, penguasa seringkali } \\
\text { melupakan janji-janji politik } \\
\text { yang kurang menguntungkan } \\
\text { dirinya, terutama terkait } \\
\text { kepentingan orang-orang } \\
\text { yang lemah. }\end{array}$ & $\begin{array}{l}\text { Ketidakamanahan penguasa terhadap } \\
\text { jabatannya (koruptif dan manipulatif) } \\
\text { adalah fenomena yang sulit untuk } \\
\text { diberantas. } \\
\text { Kemarahan masyarakat kecil adalah bom } \\
\text { waktu yang siap meledak jika dipicu dengan } \\
\text { provokasi dan masalah yang merugikan } \\
\text { mereka. }\end{array}$ \\
\hline 4 & Penguasa yang feodalistik & $\begin{array}{l}\text { Pejabat yang seharusnya } \\
\text { melayani, malah mempersulit }\end{array}$ & 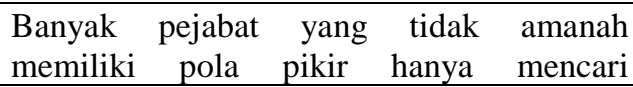 \\
\hline
\end{tabular}




\begin{tabular}{|c|l|l|l|}
\hline & & dan minta dilayani. & $\begin{array}{l}\text { keuntungan pribadi dan golongan, bukan } \\
\text { sebagai pelayan publik yang harus bekerja } \\
\text { melayani sebaik mungkin. }\end{array}$ \\
\hline 5 & $\begin{array}{l}\text { Bawahan yang patuh dan } \\
\text { menutup mata terhadap } \\
\text { ketidakamanahan penguasa/ } \\
\text { atasannya. }\end{array}$ & $\begin{array}{l}\text { Banyaknya masyarakat kecil } \\
\text { yang memanfaatkan sesama } \\
\text { masyarakat kecil demi } \\
\text { kepentingan pribadi dan } \\
\text { kepentingan orang yang lebih } \\
\text { berkuasa. }\end{array}$ & $\begin{array}{l}\text { Ironisnya, sikap oportunistik masyarakat } \\
\text { kecil yang tidak berempati dengan kesulitan } \\
\text { masyarakat kecil lainnya, semakin } \\
\text { melanggengkan lingkaran setan sikap feodal } \\
\text { dan kesewenang-wenangan penguasa yang } \\
\text { tidak amanah. }\end{array}$ \\
\hline $\begin{array}{l}\text { Solusi yang ditawarkan penulis } \\
\text { dan pernyataannya di dalam } \\
\text { naskah : }\end{array}$ & $\begin{array}{l}\text { Dialog tokoh anak-anak: } \\
\text { (KOOR) Saya orang miskin.. Saya orang miskin.. Saya orang kaya.. Saya } \\
\text { orang kaya.. Saya minta anak.. Saya minta anak.. Siapa namanya.. Siapa } \\
\text { namanya.. Namanya Cinta.. Namanya Cinta.. Cinta harus pergi ke rumah } \\
\text { orang miskin.. }\end{array}$ \\
\hline
\end{tabular}

\section{Pembahasan}

\section{A. Analisis Dramaturgi}

Analisis terhadap struktur drama dilakukan dengan membahas mengenai plot, penokohan dan tema yang terbaca dari dialog, motivasi, karakter tokoh-tokoh dan jalinan peristiwa yang dihadirkan pengarang dalam teks tertulis. Kernodle \& Kernodle (1978: 265) menjelaskan bahwa yang menjadi struktur dari unsur teater terdiri dari plot, tokoh dan tema dalam drama ketika masih berupa naskah yang belum dipentaskan. Pendapat lain juga menyebutkan bahwa konstruksi cerita drama terdiri dari tiga bahan pokok yaitu premis (tema), tokoh dan plot (Harymawan, 1988: 24). Dalam sebuah karya drama, keseluruh unsur ini harus dianalisis secara menyeluruh, karena kesemua unsurlah yang membuat jalinan kompleks ini menjadi sebuah kesatuan yang dapat diapresiasi. Seperti pendapat Gie (2004: 76-77) yang menjelaskan bahwa nilai suatu karya secara keseluruhan tergantung pada hubungan timbalbalik dari unsur-unsurnya, yakni setiap unsur memerlukan, menanggapi, dan menuntut setiap unsur lainnya bersama-sama menciptakan keutuhan untuk menciptakan keseimbangan secara estetis.

\section{Analisis Tematik}

Saini \& Sumarjo (1988:56,147,148) menjelaskan bahwa tema adalah pokok pikiran (ide) dari sebuah cerita yang akan disampaikan pengarang dalam karyanya untuk menyampaikan sesuatu, seperti masalah kehidupan, pandangan hidupnya atau komentar terhadap kehidupan ini.
Dalam tema tersebut, terdapat unsur-unsur seperti permasalahan, pernyataan, dan pesan pengarang yang disampaikan pada apresiatornya. Terhadap unsur-unsur drama yang lain, tema merupakan tujuan akhir yang harus diungkapkan melalui plot, karakter, maupun bahasa. Oleh karena itu, tema menjadi pedoman dan pemersatu bagi unsur-unsur drama lainnya. Bagian detail dari unsur tema, dapat disusun seperti bagan di bawah ini.

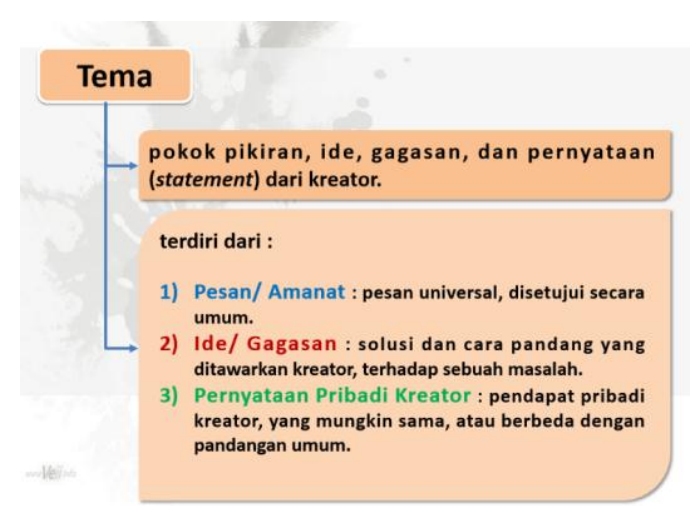

Gambar 2. Unsur-unsur Tematik dan komposisinya dalam naskah drama, serta hubungannya dengan realita yang digunakan sebagai sumber cerita.

Berdasarkan penjelasan sebelumnya, dapat disimpulkan tematik dari drama "Jalan Menyempit" seperti yang dijelaskan di bawah ini.

a) Pernyataan Kreator : ketidakseimbangan (dalam banyak hal) akan membawa malapetaka, dan cinta (dalam arti luas) adalah solusi yang dapat mengatasinya.

b) Ide / Gagasan : sesulit apapun permasalahan yang dihadapi, masih ada harapan tentang 
Dramaturgi dan Transformasi Realita dalam Naskah Drama "Jalan Menyempit" Karya Joni Faisal : Analisis Unsur Dramatik Perspekstif Sosiologi dan Psikologi

masa depan yang lebih baik, karena manusia tidak bisa hidup sendiri.

c) Pesan / Amanat : rasa cinta adalah kebutuhan hakiki manusia, walaupun persoalan hidup manusia terkadang membuatnya hilang untuk sesaat.

\section{Analisis Alur (Plot)}

Plot adalah rangkaian peristiwa yang satu sama lainnya dihubungkan dengan hukum sebab-akibat. Peristiwa demi peristiwa saling mengikat, sehingga membangun kausalitas yang tidak dapat dipisahkan. Plot juga memiliki fungsi untuk menangkap, membimbing, mengarahkan perhatian apresiator, serta mengungkapkan dan mengembangkan watak tokoh-tokoh cerita.

Abrams \& Harpharm (2009: 265) menambahkan bahwa plot dalam sebuah karya drama didasari oleh peristiwa dan tindakan yang menentukan arah pencapaian efek artistik dan emosional tertentu. Plot dan karakter saling berkaitan karena tindakan (termasuk wacana lisan maupun tindakan fisik) yang dilakukan oleh karakter tertentu dalam sebuah karya untuk menunjukkan kualitas moral dan posisi mereka. Perkembangan plot membangkitkan harapan pada penonton atau pembaca tentang masa depan peristiwa, tindakan dan respon karakter.

\section{Analisis Penokohan}

Kualitas sebuah cerita terletak pada kepandaian pengarang menghidupkan watak tokoh-tokohnya. Kepribadian yang dimiliki tokoh berhubungan dengan masa lalu, pendidikan, asal daerah dan pengalaman hidupnya. Tokoh-tokoh akan mengungkapkan perasaan dan cara berfikirnya melalui perbuatan dan apa yang dilakukannnya ketika menghadapi masalah. Maka, melalui ucapan, perbuatan, pikiran dan perasaannya, penggambaran watak yang khas dari tokoh dapat diketahui. Secara lebih detail analisis terhadap karakter/ watak dapat dilihat melalui 1) apa yang diperbuatnya, tindakannya terutama pada saat-saat kritis; 2) melalui ucapan-ucapannya; 3) melalui penggambaran fisik tokoh; 4) melalui pikiranpikirannya; dan 5) melalui penerangan langsung oleh pengarang (Saini \& Sumarjo, 1988: 64-66).
Analisis karakter melalui dialog dapat dilihat pada ; apa yang dikatakan penutur, jati diri penutur, nada suara, penekanan, dialek, kosa kata dan kualitas mental para tokoh yang tercermin dari dialognya. Sedangkan karakterisasi melalui tingkah laku para tokoh mencakup ; ekspresi wajah dan motivasi yang melandasi tindakan para tokoh (Minderop, 2005: 38).

Tokoh-tokoh cerita memiliki watak masing-masing yang digambarkan oleh pengarang sesuai dengan kemungkinan watak yang ada pada manusia seperti jahat, baik, sabar, peragu, periang, pemurung, berani, pengecut, licik, jujur, atau campuran dari beberapa watak tersebut. Watak para tokoh menjadi pendorong terjadinya peristiwa sekaligus unsur yang menyebabkan kegawatan pada masalah yang timbul dalam peristiwa tersebut sehingga dapat menggerakkan cerita. Di sinilah terdapat hubungan antara watak dengan alur cerita (Saini \& Sumarjo, 1988: 145). Ketiga pendapat inilah yang akan penulis gunakan kriteria-kriterianya untuk menganalisis penokohan dari seluruh tokoh yang dihadirkan dalam naskah drama.

$$
\text { Naskah "Jalan Menyempit" }
$$

menghadirkan tokoh-tokoh yang menjadi simbol dari manusia yang hadir di keseharian masyarakat Indonesia. Berikut ini adalah contoh pembahasan penokohan yang hadir dalam naskah drama tersebut (dua sampel tokoh).

\section{Tokoh Anak-Anak}

a. Karakter : ceria, polos, kehilangan masa kecil yang seharusnya membahagiakan.

b. Kedudukan : tokoh pelangkap yang memperkuat dramatik ironi cerita ini.

c. Fungsi : sebagai korban keadaan yang tidak bisa berbuat apa-apa, sehingga memperkuat kesan miris dari dramatik ironi yang dihadirkan.

d. Identitas :

Fisiologis : anak-anak yang masih belum sepenuhnya paham dengan apa yang terjadi di sekelilingnya.

Sisiologis : Menjadi korban keadaan, tapi tidak bisa berbuat banyak. Menghadapi kenyataan dengan kepolosan sebagaimana layaknya anak-anak.

Psikologis : polos, lugu dan tetap ceria menghadapi permasalahan hidup. 
e. Apa pesan yang ingin disampaikan pengarang cerita, melalui tokoh ini ?

Anak-anak adalah tokoh yang dihadirkan sebagai pembuka dan penutup cerita. Mereka menjadi penting sebagai tokoh yang menderita akibat persoalan di sekitarnya, tetapi tidak bisa berbuat banyak, kecuali pasrah dan berusaha terus ceria dan optimis melihat masa depan. Mereka juga menjadi korban yang tidak bersalah dari keabsurdan yang terjadi sebagai akibat pembangunan, kemajuan teknologi, dan penguasa yang tidak amanah.

\section{Tokoh Jenazah}

a. Karakter : pasrah, berfikir kritis, melihat esensi dari semua persoalan, sudah tidak peduli dengan godaan dunia.

b. Kedudukan : protagonis.

c. Fungsi : tokoh yang mewakili pemikiran pengarang untuk menyampaikan pesan, ide, gagasan, dan pernyataan yang ingin disampaikan melalui drama ini.

d. Identitas :

Fisiologis : sudah meninggal dunia, dan berbicara sebagai makhluk tidak kasat mata.

Sisiologis : dianggap penting oleh keluarganya. Psikologis : bijak, kritis, pasrah.

e. Apa pesan yang ingin disampaikan pengarang cerita, melalui tokoh ini?

Melalui tokoh surealis ini, penulis ingin menyampaikan pesan tentang absurditas yang terjadi di kesaharian masyarakat, khususnya masyarakat kecil yang menjadi korban paling menderita dari kesewenang-wenangan orang yang lebih kuat dan berkuasa. Tokoh ini menyampaikan cara pandang dan gagasan dari pengarang tentang optimisme dan cara untuk menghadapinya.

\section{Tokoh Pak Lurah}

a. Karakter : gambaran birokrat yang koruptif, manipulatif, feodal, dan egois.

b. Kedudukan : sebagai tokoh antagonis.

c. Fungsi : mempertajam ironi dan permasalahan yang terjadi di keseharian masyarakat kecil yang ditindas oleh aparat yang tidak melayani, tetapi koruptif dan manipulatif.

d. Identitas :

Fisiologis : Paruh baya.

Sisiologis : Pejabat, memegang otoritas cukup tinggi di wilayah tersebut.
Psikologis : egois, manipulatif, suka pencitraan, sok berkuasa, oportunis, dan lainlain.

e. Apa pesan yang ingin disampaikan pengarang cerita, melalui tokoh ini ?

Tokoh ini adalah penggambaran dari aparat negara yang tidak tulus melayani masyarakat untuk memberikan solusi dari setiap permasalahan, tetapi malah mempersulit keadaan untuk keuntungan diri sendiri. Kekauasaannya diraih dengan memanipulasi perasaan masyarakat yang memilihnya. Setelah berkuasa, ia melupakan janji-janji yang pernah diumbarnya.

\section{Analisis Setting}

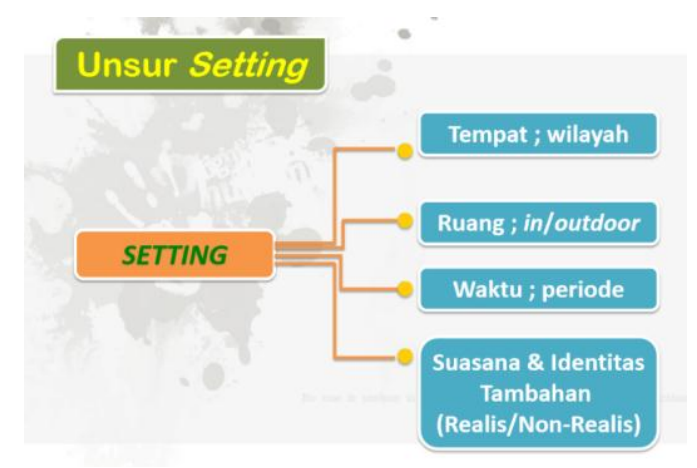

Gambar 3. Unsur-unsur Latar (Setting) yang bisa dibagi menjadi empat komponen.

Ilmu sastra mendefinisikan latar (setting) sebagai tempat kejadian cerita yang disebut juga sebagai latar cerita yang meliputi 3 dimensi yaitu ; tempat, ruang dan waktu (Waluyo, 2001:23). Sesuai dengan pendapat tersebut, Semi (1993:46) menyatakan bahwa latar adalah lingkungan tempat peristiwa terjadi, termasuk tempat/ ruang yang dapat diamati. Latar atau setting disebut juga sebagai tempat, hubungan waktu, dan lingkungan sosial tempat terjadinya peristiwa-peristiwa yang diharapkan (Fitriana, 2013).

Setting atau set-dekor adalah salah satu bagian penting dalam pertunjukan teater, yang dikenal juga dengan istilah skenografi. Di dalamnya terdapat beberapa bagian seperti set panggung, yaitu dekorasi di atas panggung, dan property (benda-benda yang dihadirkan dan bisa berpindah ; seperti meja, lemari, kursi, pohon, dan lain-lain). Terdapat juga hand-property yaitu benda-benda yang bisa dibawa-bawa oleh pemain, seperti ; kipas, buku, laptop, pulpen, 
Dramaturgi dan Transformasi Realita dalam Naskah Drama "Jalan Menyempit” Karya Joni Faisal : Analisis Unsur Dramatik Perspekstif Sosiologi dan Psikologi

belati, dan lain sebagainya. Semua ini dihadirkan sebagai penunjang bagi terciptanya ruang, waktu, dan keadaan (suasana). Penataan set-dekor dan elemen pendukungnya membutuhkan pengetahuan mengenai zaman, lokasi geografis, serta hal-hal antropologis seperti bangsa, suku, status sosial, jenis bahan, bentuk, motif dan hal mendetail lainnya. Walaupun secara visual setting dalam teater akan mewujud ketika dipertunjukkan, akan tetapi gambaran berupa deskripsi sudah dapat diketahui dari naskah dramanya. Bahkan apresiator sudah dapat mengetahui, apakah kisah ini bersifat realiskonvensianal atau absurd-surrealistik.

Naskah "Jalan Menyempit" memilih latar cerita di sebuah wilayah pemukiman padat penduduk di kota besar yang tidak disebutkan namanya secara detail. Di kota tersebut, pembangunan dilakukan secara masif dan tidak terkontrol, sehingga mengakibatkan tertutupnya jalan menuju area pemakaman. Bahkan sebuah keranda pengantar jenazah tidak bisa melalui jalan sempit akibat sebuah tembok yang baru dibangun. Area sempit sisa-sisa maraknya bangunan permanen itulah yang menjadi tempat beraktivitas masyarakat sekitar. Tentu saja hal ini menimbulkan permasalahan, seperti ketika pengusung keranda yang beradu mulut dengan penjual makanan yang membawa gerobak dorong, karena mereka sama-sama tidak mau mengalah dan merasa benar dengan kepentingannya masing-masing.

Setting naskah ini memperlihatkan perjuangan masyarakat kecil yang terpinggirkan yang bersaing dengan kekuasaan dan kekuatan ekonomi. Mereka menjadi korban dari orangorang yang sudah kehilangan nilai-nilai kemanusian akibat masifnya pembangungan dan persaingan ekonomi, keserakahan manusia, dan dampak negatif kemajuan teknologi.

Latar peristiwa memperlihatkan kondisi masyarakat kecil yang tergusur, dibiarkan berjuang sendiri, terpaksa kalah oleh kekuatan yang tidak bisa dilawannya, serta perjuangan melawan penguasa manipulatif yang tidak berpihak kepada rakyat kecil. Hal ini terwujud dalam pilihan lokasi di area masuk pemakaman, pemukiman padat penduduk, dan ruang kerja Lurah.

\section{B. Analisis Aspek Sosiologis}

Sahid (2008: 20-23) menjelaskan bahwa drama dan seni teater objeknya adalah manusia dan kebanyakan unsur-unsurnya bersifat sosial. Artinya ia merupakan norma yang tumbuh dalam kehidupan masyarakat. Sebuah karya yang diciptakan dramawan tujuannya untuk dinikmati, dipentaskan dan dimanfaatkan oleh masyarakat. Kreatornya sendiri merupakan anggota masyarakat sehingga ia terikat oleh status sosial tertentu.

Teater adalah lembaga sosial yang menggunakan bahasa, pentas, dialog, akting dan sebagainya sebagai media. Drama dan pementasan teater bisa dianggap merepresentasikan peristiwa dan gambaran kehidupan yang menjadi realitas sosial sesuai dengan perasaan, pandangan hidup dan kepekaan sosial pengarangnya. Di bawah ini, akan dijelaskan latar belakan peristiwa sosial yang terjadi di masyarakat yang diangkat ke dalam masing-masing drama.

Struktur drama dalam penelitian ini adalah pembahasan struktur intrinsik yang diambil dari bagian pendekatan strukturalisme genetik. Strukturalisme genetik dalam karya sastra meliputi unsur intrinsik dan ekstrinsik yang dikaitkan dengan situasi sosial yang ada dalam karya itu sendiri (Ratna, 2015: 123). Dalam penelitian ini yang difokuskan adalah pada unsur tema, alur, latar tempat, dan penokohan.

Swingewood (1972: 45) menyimpulkan bahwa pendekatan sosiologi sastra yang dapat dilakukan untuk melihat karya sastra sebagai dokumen budaya yang mencerminkan suatu zaman, kedudukan seorang penulis dan penerimaan suatu karya dari penulis tertentu; dan karya sastra dianggap sebagai dokumen yang mencatat unsur sosio-budaya dan dialektik, unsur budaya dalam suatu karya bukanlah setiap unsurnya, tetapi keseluruhannya yang merupakan kesatuan.

Analisis sosiologi sastra tidak dapat dipisahkan dari analisis struktur, karena karya sastra merupakan struktur yang bermakna. Karya sastra dalam pendekatan sosiologi sastra pada dasarnya memiliki dua bahan kajian. Yang pertama, teks sastra (naskah drama) merupakan 
subjek dalam kerja analisis yang berupa pemahaman tentang struktur (dramatik). Yang kedua adalah anggapan bahwa sastra merupakan cermin dari proses interaksi sosial. Sosiologi maupun sastra memiliki objek kajian yang sama, yaitu manusia dalam masyarakat, memahami hubungan-hubungan antar manusia, dan proses yang timbal-balik dari hubungan-hubungan tersebut di dalam masyarakat. Berikutnya, sosiologi dan sastra memiliki objek yang sama yaitu sastra dalam masyarakat. Akan tetapi, antara sosiologi dan sastra memiliki perbedaan. Sosiologi hanya membatasi diri pada apa yang terjadi saat ini, bukan pada apa yang seharusnya terjadi, sedangkan sastra lebih bersifat evaluatif, subjektif, dan imajinatif (Ratna, 2003: 2).

Asri (2011: 247) mengungkap relevansi sastra dengan kehidupan masyarakat dan sejauh mana sastra dapat mencerminkan kondisi masyarakat. Ia berpendapat bahwa semakin tinggi tingkat relevansi sosial-budaya masyarakat dalam karya sastra dengan realitas sosial-budaya masyarakat, maka semakin bermutu karya sastra tersebut, begitupun sebaliknya. Hal tersebut ditegaskan oleh Ratna (2015: 60) yang menyatakan bahwa pendekatan sosiologis sastra menganggap karya sastra itu milik masyarakat sehingga terjadi kaitan hakiki antara karya sastra dengan masyarakat. Kaitannya terjadi karena karya sastra dihasilkan oleh pengarang, sedangkan pengarang itu sendiri adalah anggota masyarakat. Pengarang memanfaatkan kekayaan fenomena dalam masyarakat, dan hasil karya sastra itu dimanfaatkan kembali oleh masyarakat.

Kutipan-kutipan tersebut memberikan gambaran bahwa sosiologi dan sastra selalu berhubungan dengan masyarakat. Istilah sosiologi sastra muncul dan diterapkan pada tulisan-tulisan para kritikus dan ahli sejarah sastra yang perhatian utamanya ditujukan pada cara-cara bagaimana seorang pengarang dipengaruhi oleh status kelasnya, ideologi masyarakat, keadaan-keadaan ekonomi yang berhubungan dengan pekerjaannya, dan jenis pembaca yang dituju (Abrams, 1981: 178). Kemudian Lucien Goldmann mengembangkan sosiologi sastra untuk menyatukan analisis struktural dengan matrealisme historis dan dialektik. Menurut Goldmann, karya sastra harus dipahami sebagai totalitas yang bermakna. Dalam hal ini sastra adalah fakta-fakta yang mempunyai kedudukan yang sama seperti dalam penelitian ilmiah yang dipelopori oleh Hippolyte
Taine. Pendapat ini menyatakan bahwa sastra bukanlah sekedar pencerminan masyarakatnya. Sastra merupakan usaha manusia untuk menemukan makna dunia atas nilai-nilai yang ada di dalamnya. Nilai-nilai itu harus dihayati oleh individu dan masyarakat (Faruk, 2010: 63).

\section{Analisis Aspek Psikologis}

Gejala kejiwaaan dapat terungkap lewat motivasi dan perilaku tokoh dalam sebuah karya sastra. Karya sastra yang ditulis seorang kreator merupakan hasil perenungan dan imajinasi secara sadar dari hal-hal yang diketahui, dihindari, dirasakan, ditanggapi, dan difantasikan. Kemudian hasilnya disampaikan kepada khalayak melalui media bahasa dengan segala perangkatnya, sehingga menjadi sebuah karya yang indah. Itulah sebabnya masalah-masalah yang terdapat di dalam karya sastra mempunyai kemiripan dengan keadaan di luar karya sastra. Karya sastra merupakan cermin dari dunia nyata. Proses pencerminan dari dunia nyata yang sesungguhnya, maupun cermin dari dunia nyata yang sudah bercampur dengan imajinasi dan perenungan pengarang (Siswanto, 1992: 19).

Bimo Walgito (dalam Fananie, 2000: 177) mengemukakan pendapat bahwa psikologi adalah salah satu cabang ilmu pengetahuan yang objek studinya adalah manusia, sesuai dengan asal kata psyche mengandung pengertian "jiwa". Psikologi dapat dimaknai sebagai "ilmu pengetahuan tentang jiwa", sehingga psikologi sastra berkaitan dengan unsur-unsur kejiwaan tokoh-tokoh fiksional yang terkandung dalam berbegai bentuk karya sastra.

Budi Utama (2004:138) menjelaskan tentang tiga alasan psikologi sastra masuk dalam kajian sastra adalah untuk mengetahui perilaku dan motivasi para tokoh dalam karya sastra. Secara langsung atau tidak langsung, perilaku dan motivasi para tokoh juga tampak dalam kehidupan sehari-hari. Tujuan berikutnya adalah untuk mengetahui perilaku dan motivasi pengarang dalam merekayasa tokoh dan peristiwa, sekaligus untuk mengetahui reaksi psikologi apresiator.

Hubungan antara karya sastra dan psikologi juga dikemukakan oleh Endraswara (2004:96) yang menjelaskan bahwa karya sastra dapat menghadirkan gejala psikologis karena menampilkan aspek-aspek kejiwaan melalui tokoh-tokoh yang dihadirkan. Sedangkan 
Akhyar Makaf

Dramaturgi dan Transformasi Realita dalam Naskah Drama "Jalan Menyempit" Karya Joni Faisal : Analisis Unsur Dramatik Perspekstif Sosiologi dan Psikologi

psikologi (Pasaribu dan Simanjuntak, 1984:3-4), adalah ilmu kejiwaan atau studi tentang jiwa manusia. Dapat disimpulkan bahwa karya sastra dapat dianalisis dengan menggunakan pendekatan ilmu psikologi, sebab sastra dan psikologi memiliki hubungan tidak langsung dan fungsional (Darmanto dan Roekhan dalam Aminudin, 1990:93). Maksud dari hubungan tidak langsung adalah karena sastra maupun psikologi sastra kebetulan memiliki tempat berangkat yang sama, yaitu kejiwaan manusia. Pengarang dan psikolog adalah manusia biasa. Mereka menganalisis kejiwaan manusia secara mendalam, kemudian diungkapkan dalam bentuk karya sastra. Sedangkan hubungan fungsional antara sastra dan psikologi adalah karena keduanya sama-sama berguna sebagai sarana untuk mempelajari keadaan kejiwaan orang lain. Perbedaannya terletak pada kenyataan bahwa dalam karya sastra gejala-gejala kejiwaan dari manusia-manusia imajiner sebagai tokoh dalam karya sastra, sedangkan dalam psikologi adalah gejala kejiwaan manusia-manusia riil dalam keseharian (Endraswara, 2004:97).

Berdasarkan uraian-uraian sebelumnya dapat disimpulkan bahwa pengarang mendapat inspirasi untuk mencipta dramanya salah satunya adalah dari realita sosial yang dekat dengan kehidupannya. Seperti yang dijelaskan Sahid (2008: 38) bahwa penulis pada dasarnya selalu dipengaruhi oleh lingkungan kehidupannya, interes pribadi, pengalaman hidupnya, dan bukubuku bacaannya. Melalui karyanya ia berusaha menciptakan kembali suatu dunia yang baru sebagai wahana berkomunikasi dengan masyarakatnya, sebab tidak pernah ada karya seni yang lahir dari kekosongan nilai dan norma sosial. Semi (1993:76) menambahkan bahwa pendekatan psikologi sastra adalah pendekatan yang bertolak dari pendapat bahwa karya sastra membahas tentang kehidupan manusia yang selalu memperlihatkan perilaku yang beragam.

Apresiasi sastra dengan pendekatan psikologi sastra awalnya diperkenalkan oleh L.A Richard. Di Indonesia, pendekatan ini pertama kali dilakukan oleh M.S. Hutahulung, Boen S. Oemarjati, dan Made Mukada. Selain fenomena masyarakat urban, pengarang juga menghadirkan fenomena yang jamak terjadi di Indonesia dalam satu dekade terakhir, khususnya kondisi sosial, politik dan psikologis masyarakat pasca reformasi politik yang menyebabkan perubahan sosial yang cukup besar. Beberapa dari kecendrungan masyarakat karena perubahan kondisi sosial di Indonesia umumnya, dan masyarakat perkotaan. Penulis merangkum fenomena tersebut dalam tabel yang sudah ditampilkan sebelumnya.

\section{SIMPULAN DAN SARAN}

Realita yang dihadirkan dalam naskah drama "Jalan Menyempit" adalah penggambaran dari realita sosial dan realita psikologis yang terjadi di masyarakat pada saat naskah ini ditulis. Penulisnya yang hidup di suatu zaman dan lingkungan tertentu, kemudian merespon realita yang terjadi dan menuangkan pikirannya dalam drama yang menawarkan solusi bagi konflik yang dialami masyarakat. Drama ini relevan dengan kondisi saat ini karena menghadirkan konflik yang terinspirasi dari realita sosial dan psikologis di masyarakat di perkotaan, serta menawarkan pemecahan (resolusi) yang relevan dengan masing-masing permasalahan.

Penulis menghadirkan penggambaran yang nyata dan apa adanya untuk memberikan informasi bahwa konflik yang terjadi cukup kompleks. Joni Faisal sebagai penulis naskah juga memperlihatkan kenyataan bahwa masyarakat kecil yang tertindas dan seringkali diperalat oleh orang yang lebih kuat dan berkuasa, memiliki cara tersendiri untuk mengatasinya dengan pilihan dan sudut pandang pemikiran masing-masing. Konflik yang dihadirkan akan diatasi dengan sebuah keputusan akhir untuk menghadapi setiap persoalan. Dapat disimpulkan bahwa penulis menawarkan solusi dan pesan tentang pentingnya kehadiran cinta dalam hubungan sesama manusia agar tumbuh keadilan dan kesepahaman. Penulisnya mengungkapkan kisah tentang tragedi dan ironi dengan nuansa yang satir, sehingga pesan dapat diterima oleh pembaca dan apresiator pertunjukan secara lebih efektif .

Kreator naskah ini sudah berhasil merangkai unsur-unsur dramatik dalam cerita yang disajikan, sehingga apresiator dapat memahami dengan baik konflik yang dihadirkan, serta dapat menerima pesan dan pernyataan yang 
ingin disampaikan pengarang. Begitu juga dengan realita sosial dan realita psikologis yang mudah ditemukan dalam keseharian masyarakat perkotaan, sehingga apresiator dapat menemukan relevansi setiap persoalan di dalam naskah, dengan kenyataan pada kehidupan masyarakat marjinal di Indonesia, sebagai gambaran yang mewakili kelompok masyarakat yang masih tertindas dan seringkali diabaikan.

\section{Saran}

Penelitian terhadap proses penciptaan naskah drama yang berangkat dari realita di masyarakat dapat menjadi media untuk menjelaskan fenomena dan relevansinya dengan konflik yang dihadirkan dalam naskah drama. Naskah drama menjadi dokumen yang berkontribusi dalam memetakan dan menyimpan fakta tentang fenomena dan semangat zaman di periode ketika naskah tersebut diciptakan.

Penelitian dengan objek naskah drama dapat dianalisis menggunakan teori dramaturgi untuk mengurai unsur-unsur drama yang ada dalam naskah tersebut. Selanjutnya, relevansi antara konflik dalam naskah dan realita di masyarakat dapat dikaji menggunakan pendekatan sosiologi. Sedangkan karakterisasi dari tokoh-tokoh yang dihadirkan dapat dianalisis menggunakan teoriteori psikologi.

\section{DAFTAR RUJUKAN}

Abrams, M. H. 1981. A Glossary of Literary Terms. New York: Harcourt, Brace 7 World, Inc.

Abrams, M. H., \& Harpham, Geoffrey, Galt. 2009. A Glossary of Literary Terms. Wadsworth Cengage Learning.

Aminuddin. 1990. Pengembangan Penelitian Kualitatif dalam Bidang Bahasa dan Sastra. Malang: Yayasan Asih Asah Asuh.

Asri, Y. 2011. "Analisis Sosiologis Cerpen Si Padang Karya Ardini Pangastuti B. N." dalam Jurnal Humaniora Vol. 23 (3), 245-255.
Endraswara, Suwardi. 2004. Metodologi Penelitiaan Sastra. Yogyakarta. Pustaka Widyatawa.

Faisal, Joni, dkk. 2017. 10 Lakon Indonesia 2017, Pemenang Lomba Penulisan Naskah Lakon Teater 2017. Jakarta. Direktorat Kesenian, Direktorat Jenderal Kebudayaan, Kementerian Pendidikan dan Kebudayaan.

Fananie, Zainuddin. 2000. Telaah Sastra. Surakarta: Muhammadiyah University Press.

Faruk. 2010. Pengantar Sosiologi Sastra. Yogyakarta: Pustaka Pelajar.

Fitriana, Y. 2013. Struktur dan Simbol-Simbol dalam Teks Drama "Orang-Orang Kalah” Karya Hang Kafrawi. Atavisme, 16(1), 109-118. Graha Widya.

Harymawan. RMA. 1988. Dramaturgi. Bandung. CV. Rosda.

Kernodle, George \& Portia Kernodle. 1978. Invitation to The Theatre. Brief Second Edition. New York. Harcourt Brace Jovanovic.

Minderop, Albertine. 2005. Metode Karakterisasi Telaah Puisi. Jakarta. Yayasan Obor Indonesia.

Nurgiyantoro, B. 2005. Teori Pengkajian Fiksi. Yogyakarta: Gadjah Mada University Press.

Pasaribu \& Simanjuntak. 1984. Sosiologi dan Pembangunan. Bandung. Tarsito.

Ratna, Nyoman Kutha. 2010. Metodologi Penelitian.Kajian Ilmu Budaya dan Ilmu Sosial Humaniora Pada Umumnya. Yogyakarta. Pustaka Pelajar.

$\begin{array}{ll}\text { dan Teknik } & \begin{array}{c}2015 . \text { Teori, Metode, } \\ \text { Penelitian } \\ \text { Yogyakarta. Pustaka Pelajar. }\end{array}\end{array}$

Riantiarno, N. 2011. Kitab Teater, Tanya Jawab Seputar Seni Pertunjukan. Jakarta. Grasindo. 
Dramaturgi dan Transformasi Realita dalam Naskah Drama "Jalan Menyempit" Karya Joni Faisal : Analisis Unsur Dramatik Perspekstif Sosiologi dan Psikologi

Sahid, Nur. 2008. Sosiologi Teater. Yogyakarta. Pratista.

Semi, Atar. 1993. Metode Penelitian Sastra. Bandung: Angkasa Raya.

Siswanto, Wahyudi. 1992. Psikologi Sastra. Malang. OPF IKIP Malang.

Sitorus, Eka D. 2002. The Art of Acting Seni Peran untuk Teater, Film \& TV. Jakarta. Gramedia.

Soemardjo, Jakob \& Saini, K.M. 1988. Apresiasi Kesusasteraan. Jakarta . P.T. Gramedia Pustaka Utama.

Swingewood, A., Diana Lorenson. 1972. The Sociology of Literature. Paladine.

Waluyo, Herman J. 2001. Drama Teori dan Pengajarannya. Yogyakarta: PT. Hanindita. 